\title{
PENGEMBANGAN POTENSI SUMBER DAYA ALAM DI DESA ULAK PANDAN KABUPATEN OGAN KOMERING ULU
}

\author{
Angga Wibowo Gultom \\ Fakultas Ekonomi dan Bisnis, Universitas HKBP Nommensen
}

\begin{abstract}
Abstrak
Setiap wilayah tentu memiliki sumber daya alam yang dapat dimanfaatkan oleh masyarakat untuk diolah dan dijadikan sumber pendapatan. Sumber daya alam yang baik adalah sumber daya alam yang tidak dijual mentah namun harus diolah dan dijadikan suatu produk sehingga nilai guna dan nilai ekonomis dari sumber daya alam tersebut menjadi tinggi. Sesuai dengan undang-undang, salah satu unsur yang bertugas untuk mengolah dan mengembangkan potensi sumber daya alam untuk memiliki nilai yang tinggi adalah desa. Desa memiliki peran yang sangat penting untuk menentukan kemana arah pengelolaan sumber daya yang mereka miliki. Desa yang aktif dan kreatif akan memaksimumkan potensi sumber daya alam yang mereka miliki sehingga mendatangkan nilai ekonomi yang dapat mensejahteraan warganya. Munculnya desa mandiri dan desa yang maju dimulai dari pemahaman yang benar akan potensi sumber daya alam yang dimiliki dan mulai mengolahnya dengan tepat dan terencana. Untuk itu kegiatan pengabdian pada masyarakat ini dilakukan, agar dapat meningkatkan pemahaman dan membuka pola pikir para perangkat dan warga desa tentang bagaimana cara mengembangkan potensi sumber daya alam yang ada didesa mereka. Kegiatan pengabdian pada masyarakat ini dilaksanakan dengan metode presentasi dan diskusi bertempat di aula desa. Hasil dari pengabdian ini akan menyimpulkan potensi apa yang dimiliki oleh desa ulak pandan dan bagaimana cara agar desa ulak pandan mengembangkan potensi yang telah mereka miliki tersebut, dengan harapan agar desa ulak pandan dapat menjadi desa yang lebih maju dimasa yang akan datang.
\end{abstract}

\section{Kata Kunci: Pengembangan, Potensi Sumber Daya Alam, Desa}

\begin{abstract}
Each region certainly has natural resources that can be used by the community to be processed and used as a source of income. Good natural resources are not sold raw but must be processed and made into a product so that the economic value of these natural resources are high. Based on rules, one of the elements in charge of cultivating and developing natural resource potentials to have high value is the village. Villages have a very important role in determining how to manage their resources. Villages that are active and creative will maximize the potential of their natural resources to bring economic value and welfare of their citizens. The emergence of independent villages and developed villages started from a correct understanding of their natural potential resources and began to process them appropriately and well planned. For this reason, this community service activity is carried out, in order to increase the understanding and open the mindset of the apparatus and villagers on how to develop the natural potential resources in their village. This community service activity is carried out by means of presentation and discussion methods taking place in the village hall. The results of this service will conclude what potential the ulak pandan village has and how to make the ulak pandan village develop their natural potential resources with the hope that the ulak pandan village can become a more advanced village in the future.
\end{abstract}

Keywords: Development, Potential, Natural Resources, Village

Correspondence author: Angga Wibowo Gulton, mr.angga.gultom@gmail.com

Medan, Indonesia 


\section{PENDAHULUAN}

\section{Latar Belakang Masalah}

Posisi desa dalam memberikan kontribusi terhadap pembangunan negara memang sangat strategis, hal ini bisa dilihat dari peran desa sebagai ujung tombak yang mampu mengidentifikasi kebutuhan masyarakat di bagian akar rumput hingga membuat perencanan pembangunan yang berkelanjutan (Sidik, 2015). Untuk itulah pemerintah melalui undang-undang mendorong desa agar dapat berkembang dan menjadi desa yang mandiri yang diwujudkan dengan memberikan alokasi dana desa untuk dikelola dengan jumlah mulai dari 800 juta hingga 1,4 miliar per desa (Saputra et al., 2019). Untuk melaksanakan pengelolaan desa, dilakukan dengan dua arah, yaitu perencanaan partisipatif dan perencaan teknokratik, perencanaan ini dibuat dan dilaksanakan untuk mewujudkan pembangunan kawasan desa (Soleh, 2017).

Sejak disahkan, undang-undang desa telah memberikan banyak perubahan desa kearah yang lebih baik karena undang-undang ini secara khusus memberikan tugas kepada perangkat desa untuk mengurus, mengatur dan memanfaatkan asset sumber daya alam yang dimiliki desa untuk kemajuan serta kesejahteraan desa (Presiden Republik Indonesia, 2014). Undang-undang ini pun menjadi pondasi akan pelaksanaan otonomi yang bisa dilakukan oleh desa untuk mengatur serta mengurus berbagai keperluan rumah tangga desa mereka sendiri, termasuk mengelola serta memanfaatkan sumber daya alam yang dimiliki oleh desa tersebut (Zakiyah \& Idrus, 2017). Namun demikian, sumber daya yang dikelola oleh desa ini tidak dapat dilakukan secara semena-mena dan tidak bisa dieksploitasi secara berlebihan, karena tujuan dari pengelolaan sumber daya alam ini adalah kebermanfaatan bagi masyarakat (“Pengelolaan Sumber Daya Alam Berbasis Kelembagaan Lokal," 2011).

Berdasarkan hasil penjabaran diatas maka dapat diketahui bahwa desa memiliki peranan yang sangat penting dalam pengelolaan potensi desa untuk memberikan kesejahteraan bagi masyarakatnya. Potensi yang dimiliki desa dapat dimanfaatkan untuk dijadian bahan evaluasi dan analisis kewilayahan terkait dengan potensi ekonomi, sosial, sarana prasarana serta dapat digunakan untuk melakukan evaluasi program yang telah dilaksanakan sebagai dasar dalam menyusun berbagai kebijakan strategis berbasis kewilayahan (Badan Pusat Statistik, 2018). Secara umum pengembangan potensi desa adalah untuk mendorong masyarakat yang mandiri 
dengan memanfaatkan potensi unggulan sumber daya alam untuk dikembangkan (Soleh, 2017). Untuk mengembangkan potensi desa yang maksimal, dibutuhkan peran serta masyarakat yang aktif dan kolaboratif atau dikenal dengan istilah pemberdayaan masyarakat yang terbukti mampu mengatasi permasalahan sosial terutama untuk pengentasan kemiskinan di desa (Widayanti, 2012).

Melalui pemberdayaan masyarakat maka akan menjadi solusi bersama bagi desa untuk keluar dari permasalahan kemiskinan yang mereka hadapi, pemberdayaan masayrakat juga dapat membuat masyarakat menjadi lebih mandiri dalam menjalani kehidupan mereka sehari-hari ( et al., 2017). Pemberdayaan masyarakat dalam mengelola sumber daya alam yang dimiliki oleh desa bisa dimulai dari kesamaan akan pemahaman tentang rencana dan tujuan yang akan dicapai, karena desa yang berhasil dan maju dalam pengelolaan sumber daya alam tidak bisa dicapai dengan mudah, melainkan harus dimulai dari srategi serta perencanaan yang matang sehingga dapat menghasilkan ouput produk yang memiliki nilai jual tinggi yang pada akhirnya dapat meningkatkan kesejahteraan bersama (Zakiyah \& Idrus, 2017).

Potensi sumber daya alam yang besar serta diikuti dengan sistem pengelolaan yang baik tentu akan menghasilkan masyarakat yang sejahtera, hal ini juga yang menjadi rencana dan tujuan strategis di desa Ulak Pandan Kabupaten Ogan Komering Ulu. Desa yang terkenal dengan banyak potensi sumber daya alam mulai dari hasil panen pertanian yang melimpah serta letak geografis bukit dan sungai yang indah tentu menjadikan desa Ulak Pandan memiliki banyak keuntungan dibidang geografis dan pertanian. Namun demikian sumber daya alam ini belum dimanfaatkan secara optimal sehingga belum memberikan dampak signifikan terhadap kesejahteraan masyarakat. Untuk itulah kegiatan pengabdian kepada masyarakat ini dilakukan, agar masyarakat di desa ulak pandan memiliki pemahaman yang sama akan potensi sumber daya alam yang mereka miliki dan memiliki tujuan serta strategi yang jelas dimasa depan terkait pengelolaan yang akan dilakukan. kegiatan ini dilakukan dengan metode presentasi dan diskusi yang dilakukan bersama para pejabat struktural desa, tokoh masyarakat, serta masyarakat umum yang bertempat di balai desa Ulak Pandan Kabupaten Ogan Komering Ulu.

\section{METODE PELAKSANAAN}

Kegiatan ini dilaksanakan pada bulan Agustus 2019 bertepatan dengan kegiatan Kuliah Kerja Nyata (KKN) Universitas Baturaja di desa Ulak Pandan 
Kabupaten Ogan Komering Ulu. Kegiatan ini bertempat di Aula desa yang dihadiri oleh pejabat struktural desa, tokoh masyarakat, serta masyarakat umum. metode yang digunakan dalam pelaksanaan pengabdian pada masyarakat ini ada dua, yang pertama presentasi dengan menggunakan alat infokus serta proyektor dengan slide powerpoint, yang kedua ialah diskusi serta tanya jawab antara pemateri dan peserta kegiatan.

Secara lebih rinci metode kegiatan pengabdian pada masyarakat dengan tema pengembangan potensi sumber daya alam di desa ulak pandan kabupaten Ogan Komering Ulu akan dijelaskan sebagai berikut :

\section{Tahapan Presentasi}

1. Alat yang digunakan dalam penyampaian materi adalah infokus dan proyektor dengan tampilan slide powerpoint.

2. Penjelasan pemateri dilakukan dengan satu arah, dan setiap peserta menyimak paparan dari pemateri sembari mempersiapkan pertanyaan atau hal yang nantinya akan didiskusikan.

3. Materi yang diberikan pada tahap ini adalah pengertian potensi desa, bagaimana cara memanfaatkan sumber daya alam desa, dan menjelaskan berbagai contoh desa yang telah mandiri karena berhasil mengelola sumber daya alamnya.

4. Materi dipaparkan dengan kajian literatur dan contoh kasus terkini.

\section{Tahapan Diskusi}

1. Merupakan proses komunikasi dua arah antara pemateri dan peserta kegiatan, dalam tahapan ini peserta secara bebas menyampaikan berbagai pertanyaan ataupun hal yang ingin didiskusikan terkait dengan pemaparan materi yang telah diberikan ataupun tema yang sedang didiskusikan dalam kegiatan ini.

2. Peserta secara tertib mulai memberikan berbagai pertanyaan terkait potensi sumber daya alam yang ada di desa ulak pandan kabupaten Ogan Komering Ulu sehingga proses kegiatan menjadi sangat aktif dan interaktif.

3. Selain pertanyaan, dalam metode diskusi ini peserta diperkenankan untuk menyampaikan berbagai pendapat mereka tentang pengelolaan sumber daya alam di desa Ulak Pandan. 
4. Untuk tertibnya acara, maka moderator akan memandu kegiatan metode diskusi ini, sehingga banyaknya pertanyaan dan penyampaian pendapat tetap dalam kondisi yang tertib dan konsdusif.

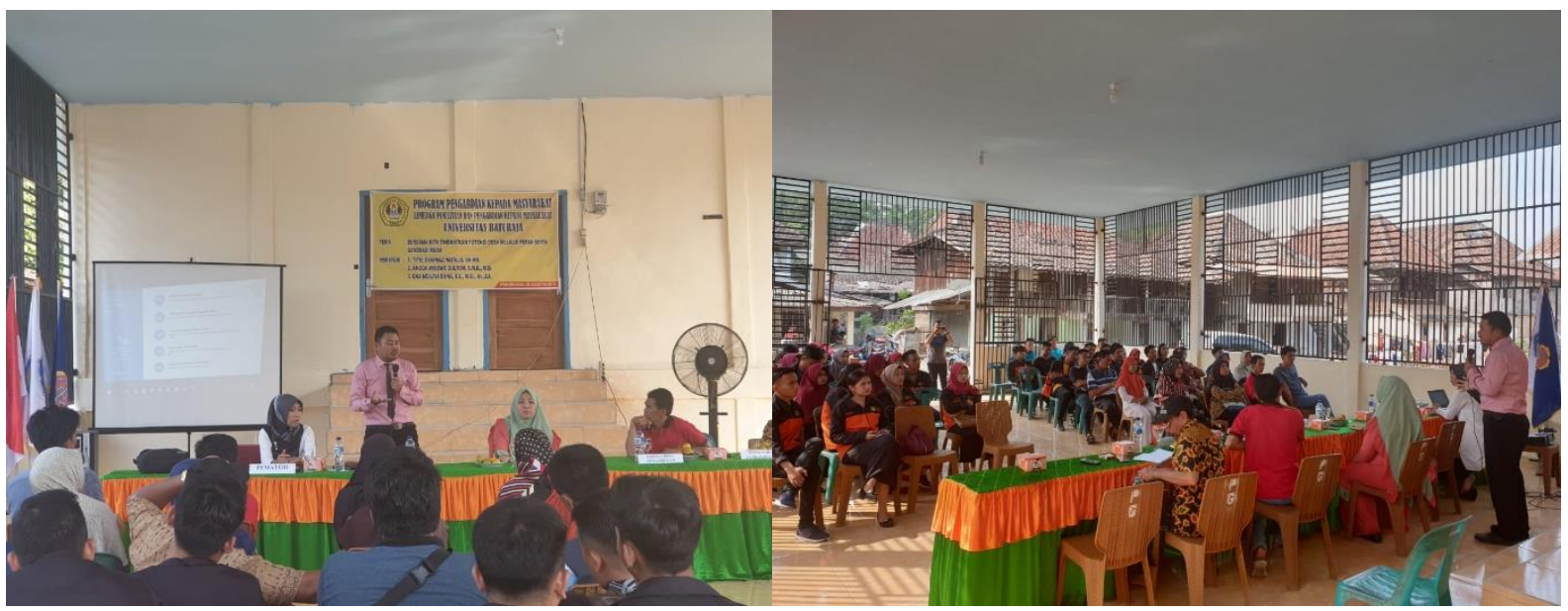

Gambar 1. Foto Penyampaian Materi Melalui Metode Presentasi

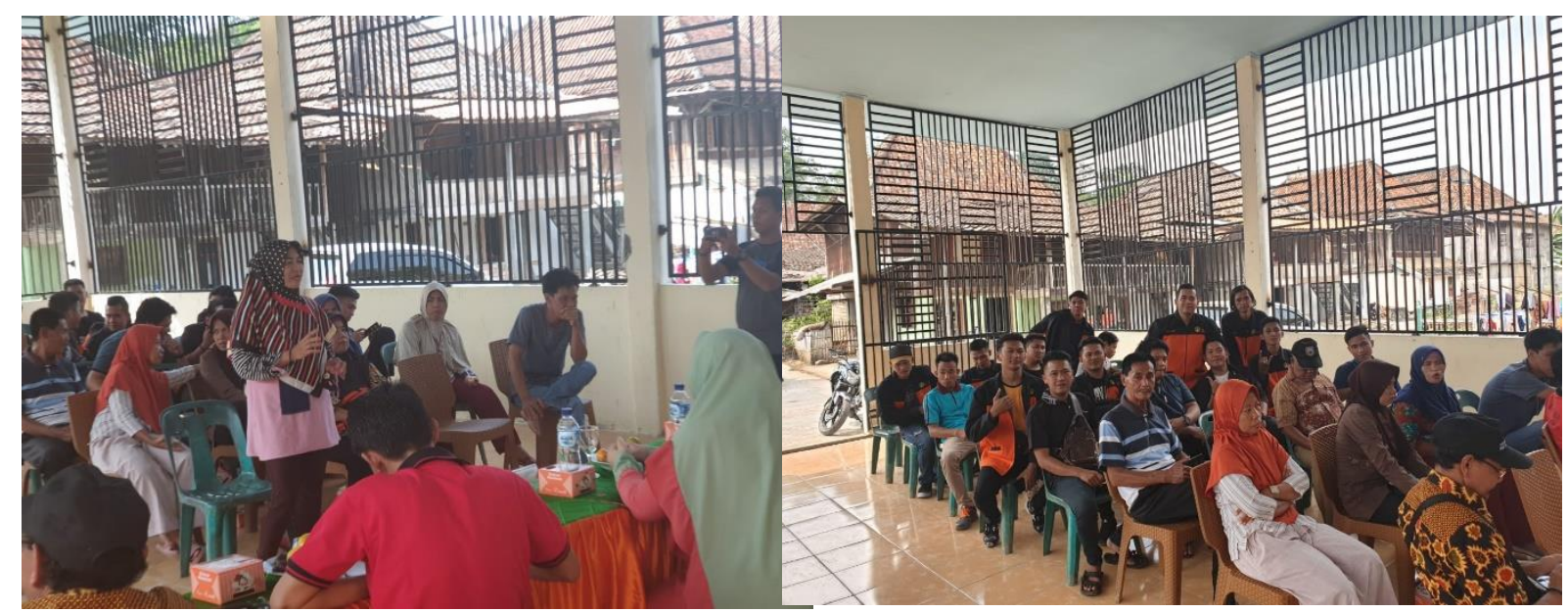

Gambar 2. Foto Diskusi Dan Penyampaian Pendapat Dari Peserta Kegiatan 


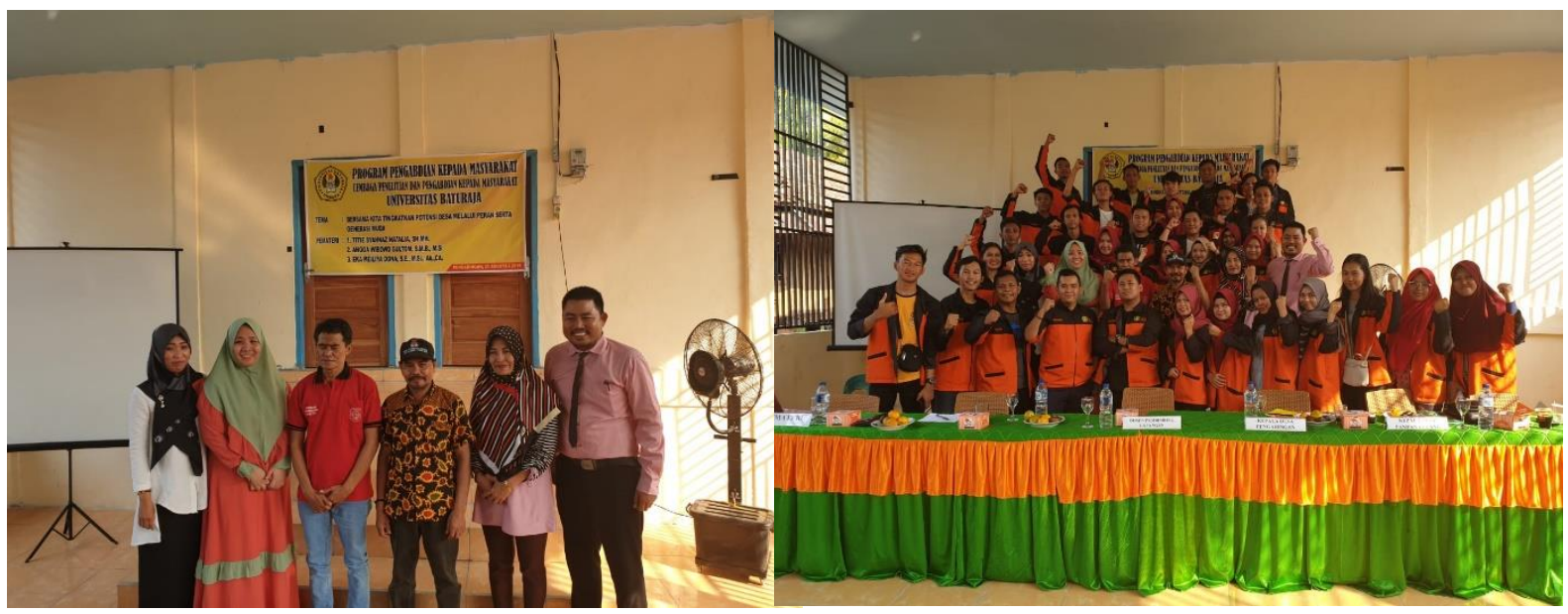

Gambar 3. Foto Bersama Perangkat Desa Dan Mahasiswa

\section{HASIL DAN PEMBAHASAN}

Hasil kegiatan pengabdian pada masyarakat tentang pengembangan potensi sumber daya alam di desa Ulak Pandan Kabupaten Ogan Komering ulu dapat dilihat dari pemahaman masyarakat yang hadir dalam proses presentasi dan diskusi yang dilakukan. Adapun hasil yang didapat dalam kegiatan ini adalah sebagai berikut:

\section{Tingkat pemahaman masyarakat terhadap potensi sumber daya alam}

Setelah melakukan presentasi dan diskusi maka didapatkan hasil bahwa masyarakat desa Ulak Pandan Kabupaten Ogan Komering Ulu hanya terpaku terhadap sumber daya alam kelapa sawit dan karet saja, mengingat sebagian besar masyarakat desa Ulak Pandan memang menggantungkan perekonomian keluarga mereka dari kedua hasil kebun ini. Hasil sumber daya alam kelapa sawit biasa dijual masyarakat ke perusahaan, sedangkan untuk karet dijual kepada tengkulak. Kedua hasil sumber daya alam ini memang tidak bisa diolah lebih lanjut oleh desa mengingat dibutuhkan teknologi tinggi dan skala level pabrik yang besar. Namun berdasarkan hasil diskusi bersama didapat tambahan sumber daya alam lain yang dapat diolah selain sawit dan karet, yaitu kelapa dan pinggir aliran sungai.

Desa Ulak Pandan ternyata menjadi salah satu desa yang memiliki banyak pohon kelapa dan memiliki kontur aliran sungai yang indah dan bagus. Kedua sumber daya alam ini merupakan potensi desa yang dapat diolah lebih lanjut oleh desa dan masyarakat. Selama ini kelapa hanya dijual mentah per butir untuk memasok kebutuhan pasar di kabupaten Ogan Komering Ulu, sedangkan untuk pinggir aliran 
sungai yang indah belum diolah untuk dimaksimalkan menjadi tempat wisata, hanya dijadikan tempat foto dan nongkrong bersama oleh pemuda karang taruna setempat saja.

Hasil dari diskusi menyimpulkan bahwa potensi kelapa yang dimiliki oleh desa Ulak Pandan dapat diolah menjadi nata the coco, karna ternyata ada ibu-ibu di desa ini yang pernah mengikuti pelatihan pembuatan nata the coco namun belum sempat diaplikasikan di masyarakat. Selain itu kelapa juga bisa diolah menjadi minyak kelapa VCO ataupun santan yang kemudian dijadikan bahan baku pembuatan kue tradisional seperti bolu pandan dan srikaya. Melalui olahan makanan dari kelapa ini diharapkan dapat menjadi jalan untuk pemberdayaan masyarakat terutama ibu-ibu dan juga menciptakan produk unggulan desa di bidang kuliner makanan khas.

Untuk pinggir aliran sungai, dari diskusi didapatkan hasil bahwa sumber daya alam tersebut akan diolah dan diperkenalkan untuk menjadi objek wisata dan rekreasi keluarga bagi masyarakat sekitar daerah Ulak Pandan terutama dari daerah kota Baturaja yang hanya berjarak 25 menit. Objek wisata ini nantinya akan diperkenalkan dan di Kelola oleh karang taruna agar menjadi tempat yang kekinian dan viral untuk memotivasi masyarakat beramai-ramai datang ke lokasi ini.

\section{Tingkat optimisme masyarakat dalam mengolah sumber daya alam}

Hasil presentasi dan diskusi juga menunjukan bahwa tingkat pemahaman masyarakat dalam mengolah sumber daya alam masih sangat membutuhkan motivasi, dorongan dan pembinaan agar masyarakat lebih paham dan mengerti untuk melakukan tindakan yang tepat dalam mengolah sumber daya alam tersebut. Keluarnya ide akan olahan kelapa dan alternatif wisata lokal berbasis pinggir sungai yang dikelola oleh karang taruna desa adalah hasil dari diskusi bersama setelah dipaparkan tentang pemahaman melalui presentasi bahwa sumber daya alam yang potensial untuk dikembangkan itu tidak berarti harus berasal dari hasil kebun saja, tapi juga bisa berasal dari keadaan alam dan kondisi lingkungan sekitar desa. Dengan adanya presentasi dan diskusi dari kegiatan pengabdian masyarakat ini maka dapat diketahui bahwa pemahaman masyarakat akan potensi desa mulai meningkat terbukti dari adanya ide-ide baru yang lebih segar dan kekinian untuk dieksekusi dan dikembangkan oleh masyarakat sekitar. 
Kegiatan pengabdian pada masyarakat inipun mulai menginspirasi desa untuk melaksanakan kegiatan serupa untuk memotivasi dan membuka wawasan masyarakat agar ide-ide baru terkait kolaborasi pemberdayaan masyarakat dan aparatur desa tentang pengelolaan sumber daya alam di desa Ulak Pandan dapat berjalan lebih baik dan kedepannya dapat dituangkan kedalam program kerja unggulan desa. Semangat dan antusiasme peserta dalam kegiatan ini secara tidak langsung telah menumbuhkan rasa optimisme bagi warga dan aparatur desa untuk saling bahu-membahu mewujudkan desa yang lebih maju dan mandiri.

\section{Tingkat pemahaman masyarakat dalam kerjasama instansi}

Berdasarkan hasil kegiatan pengabdian kepada masyarakat ini, diketahui bahwa masyarakat masih sangat awam tentang kerjasama dengan berbagai instansi pemerintahan dan swasta dalam mengembangkan produk lokal yang mereka miliki, sehingga terkadang masyarakat merasa pesimis duluan untuk mengembangkan ide produk yang mereka miliki. Sebagai contoh apabila mereka mau membuat produk olahan kelapa seperti nata the coco, maka mereka akan kebingungan bagaimana cara membuatnya, cara memasarkan produknya dan bagaimana cara mnghitung untung dan rugi untuk menentukan harga jualnya akan tetap kompetititf di pasar.

Karena masih merasa awam dibanyak hal tersebut, sehingga terkadang membuat warga masyarakat menjadi enggan dan tidak termotivasi untuk mengeksekusi ide yang sebenernya sudah mereka miliki. Untuk itulah para warga dan aparatur desa membutuhkan banyak kerjasama instansi baik pemerintah maupun swasta untuk membimbing mereka dalam mengembangkan potensi sumber daya alam yang mereka miliki. Karena tanpa arah bimbingan dan panduan yang jelas dan ahli yang dapat membantu mendampingi mereka dari proses hulu ke hilir dari produk yang mereka buat, dikhawatirkan produk ini tidak akan diterima pasar sehingga potensi sumber daya alam yang dimilikipun tidak dapat dimaksimalkan dengan baik.

Peran aktif aparatur desa sangat diperlukan untuk mengembangkan kolaborasi dengan berbagai instansi agar optimisme masyarakat dalam mengelola produk hasil sumber daya alam desa dapat tersalurkan dengan baik. Kolaborasi ini dapat dimulai bersama pihak Universitas, instansi pemerintahan terkait seperti dinas pariwisata, Koperasi dan UMKM, Dinas Kesehatan, termasuk juga instansi swasta seperti toko retail, mini market dan supermarket agar produk hasil olahan sumber daya alam di 
desa Ulak Pandan dapat dengan mudah diakses dan dibeli oleh masyarakat luas sehingga kemandirian dan kesejahteraan masayarakat desa dapat tercapai.

\section{Alternatif sumber daya lain untuk dieksplorasi}

Selain sumber daya alam yang masih sangat luas untuk dimanfaatkan bagi warga masyarakat dan aparatur desa, terdapat juga sumber daya lain yang sebenernya sangat potensial untuk dikembangkan sebagai produk unggulan desa. Sumber daya tersebut berasal dari tangan-tangan kreatif ibu-ibu kelompok PKK yang saat ini telah membuat kreasi anyaman berbahan dasar tali kur dan anyaman bungkus plastik bekas kopi serta deterjen. Saat ini sudah banyak produk yang dihasilkan, namun mayoritas masih berbentuk tas, seperti tas rajut tali kur, maupun tas plastik dan keranjang. Tangantangan kreatif ibu-ibu ini termasuk potensi desa yang bisa dikembangkan bagi warga dan aparatur desa untuk dijadikan salah satu produk unggulan desa.

Namun demikian, produk kreatif ini hanya dijadikan pengisi waktu luang saja dan tidak bisa dijadikan sumber pendapatan utama, mengingat produk hanya dibuat berdasarkan pesanan yang datang dari warga sekitar saja. Pemasaran kembali menjadi kendala masyarakat dalam menyalurkan produk mereka. Untuk itu dibutuhkan banyak pembinaan terkait dengan inovasi produk dan bentuk yang inovatif dari hasil anyaman rajut tali kur dan tas plastik ini mengingat produk ini adalah produk yang mudah ditemukan dan dibuat oleh setiap orang dengan nilai diferensiasi produk yang rendah. Untuk itu diberikan berbagai alternatif untuk pemasaran produk ini diantaranya ialah membuat tas tali kur dengan motif ciri khas desa ulak pandan sehingga menjadi unik dan kreatif untuk menonjolkan identitas dan karakter desa ulak pandan.

\section{KESIMPULAN}

Berdasarkan hasil kegiatan pengabdian pada masyarakat tentang pengembangan potensi sumber daya alam di desa Ulak Pandan Kabupaten Ogan Komering ulu, dapat disimpulkan bahwa desa ulak pandan memiliki banyak potensi sumber daya alam yang dapat diolah oleh warga masyarakat dan aparatur desa. Sumber daya alam yang saat ini sudah diolah ialah kelapa sawit dan tanaman karet. Namun potensi sumber daya alam yang belum diolah dan dapat lebih dimaksimalkan adalah kelapa dan pinggir aliran sungai. Kelapa akan dimanfaatkan menjadi olahan berbagai produk makanan seperti nata the coco dan kue khas daerah, sedangkan pinggir 
aliran sungai akan dijadikan tempat wisata kekinian yang diolah oleh karang taruna desa dengan segmen masyarakat yang membutuhkan tempat rekreasi yang sejuk dan alami.

Dibutuhkan proses pembinaan rutin yang berkelanjutan dari pihak pemerintah maupun pihak swasta untuk mendukung terwujudnya desa Ulak Pandan menjadi desa yang mandiri sesuai dengan harapan pemerintah. Pembinaan ini harus difokuskan untuk menjaga semangat dan motivasi para warga masyarakat dan aparatur desa akan kepastian hulu dan hilir dari berbagai produk inovasi yang mereka ciptakan dengan memanfaatkan sumber daya alam yang dimiliki di desa mereka. Dengan kepastian pasar, maka akan membuat masyarakat lebih kreatif dan inovatif dalam mengolah sumber daya alam. Selain sumber daya alam, terdapat juga sumber daya lain yang dapat dimanfaatkan, yaitu sumber daya kreatif dari warga desa yang mampu membuat kerajinan dari tali kur dan plastik bekas. Namun demikian masih tetap dibutuhkan pembinaan dan inovasi untuk membuat produk ini dapat diterima dengan baik oleh pasar yang ada.

\section{DAFTAR PUSTAKA}

M., Kusniawati, D., Setyaningrum, B., Prasetyawati, E., \& Islami, N. P. (2017)., Pemberdayaan Masyarakat Berbasis Potensi Lokal Melalui Program Desa Wisata di Desa Bumiaji. Sosioglobal: Jurnal Pemikiran Dan Penelitian Sosiologi. https://doi.org/10.24198/jsg.v2i1.15282

Badan Pusat Statistik. (2018)., Statistik Hasil Pendataan Potensi Desa (Podes) 2018, Badan Pusat Statistik:Jakarta.

Pengelolaan Sumber Daya Alam Berbasis Kelembagaan Lokal. (2011)., Citra Lekha.

Presiden Republik Indonesia. (2014)., Undang-Undang Nomor 6 Tahun 2014 Tentang Desa. In Undang-undang.

Saputra, K. A. K., Pradnyanitasari, P. D., Priliandani, N. M. I., \& Putra, I. G. B. N. P. (2019)., Praktek Akuntabilitas Dan Kompetensi Sumber Daya Manusia Untuk Pencegahan Fraud Dalam Pengelolaan Dana Desa. Krisna: Kumpulan Riset Akuntansi.

Sidik, F. (2015)., Menggali Potensi Lokal Mewujudkan Kemandirian Desa. JKAP (Jurnal Kebijakan Dan Administrasi Publik). https://doi.org/10.22 146/jkap.7962 
Soleh, A. (2017)., Strategi Pengembangan Potensi Desa. Jurnal Sungkai.

Widayanti, S. (2012)., Pemberdayaan Masyarakat: Pendekatan Teoritis. In Ilmu Kesejahteraan Sosial.

Zakiyah, U., \& Idrus, I. A. (2017)., SRATEGI PENGELOLAAN SUMBER DAYA ALAM DESA PONGGOK. JIP (Jurnal Ilmu Pemerintahan): Kajian Ilmu Pemerintahan Dan Politik Daerah. https://doi.org/10.24905/jip.2.2.2017.84-95 